\title{
EDITOR'S PREFAGE
}

TO invoke the aid of an electronic computer in mapping Yeats's private worlds of myth and symbol and Irish legend may well arouse disquiet. What humanist can remain undisturbed at the cold prospect of tabulating cones ( 1 occurrence), cubes (2), and gyres (14, in its various forms)those magical designs which, Yeats tells us, "Robartes describes the Judwali Arabs as making upon the sand for the instruction of their young people, and which, according to tradition, were drawn as described in sleep by the wife of Kusta-Ben-Luka"? But the reader of Yeats who can learn to tolerate these ironies will find in this concordance (produced on an IBM 704 Electronic Data Processing Machine) information never before readily accessible. For this is, I believe, the first concordance of a symbolist poet ever undertaken. Apart from the ordinary uses of such an index, the reader has available here the means of tracing surely and in intricate detail the language patterns of a symbolist imagination.

Consider, to take an elementary instance, the advantages of cataloguing the extraordinary birds that beat, wheel, cry, hover, and keen through Yeats's poems. Birds, to be sure, warble outrageously through all English poetry; in some peculiar way they express the national genius. But a full inventory of this Irish poet's birds overwhelms the mind. I count, for a beginning, some 8 hawks, 21 owls, 6 bats, 2 kites, 6 falcons, 15 eagles, 8 ospreys, and 5 kingfishers-all birds of prey-as well as 2 robins, 2 partridges, 2 gannets, 9 swallows, 3 water-hens, 2 water-fowls, 4 moorhens, 2 peahens, 3 moorfowl, 10 herons, 12 curlews, 3 bitterns, 6 gulls, 2 seagulls, 1 sea-mew, 10 doves, 1 ringdove, 4 pigeons, 1 crane, 2 nightingales, 5 sparrows, 4 parrots, 2 crows, 11 cocks, 4 hens, 13 peacocks, 1 daw, 2 rooks, 1 stare, 1 nightjar, 2 lapwings, 1 jay, 1 cormorant, 1 grouse, 2 ducks, 16 swans, 6 ravens, 2 woodpeckers, 3 flamingos, 4 linnets, 2 snipes, 4 peewits, 8 geese, 1 barnacle-goose, 1 turkey, and 6 cuckoosnot to speak of the halcyon (3), the phoenix (8), or the bird that Grecian goldsmiths make. "Bird," incidentally, has 163 occurrences in all its forms, not counting such compounds as "gamebird" (2), "cattle-birds" (1), "sea- 
bird" (2), and "song-bird" (2). To carry on a study of bird imagery one would, of course, have not only to complete the inventory, but also to move out through such associated words as "bill," "wing," "feather," "claw," "pinion," "perch," "nest," "cage," and "flutter." And one might appropriately hunt down Yeats's other winged creatures-wasps (1), bees (39), moths (18), grasshoppers (7), flies (27), and the like, ending perhaps with vampire (1) and muse (11).

The symbolic importance of Yeats's birds has been recognized by critics and scholars. Yeats's landscape world of images, we all agree, is a forest of trees (each with a mask hanging on the trunk), their branches alive with birds-a forest running along the edge of the sea, broken by an occasional house with a tower and a rose garden, and overhead (though not all at once) the sun, the moon, and the stars. But one might wonder whether (save for the rough beast that slouches toward Bethlehem) the animals that thickly populate this forest have aroused the interest they deserve. As the concordance reveals, savage or noxious animals (analogous, perhaps, to the birds of prey) abound: 3 leopards, 3 bears, 6 panthers, 9 wolves, 20 lions, 7 weasels, 12 foxes, 1 rat, 1 rhinoceros, 5 boars, 3 adders, 3 lynxes, 4 spiders, 4 serpents, 18 worms, 1 polecat, and 1 mole. But animals of every sort-wild and domestic, large and small, four-legged and aquatic-throng the poems. I count, loosely, 72 horses (also 2 stallions, 5 mares), 23 hares, 3 asses, 1 jackass, 2 antelopes, 33 deer (plus 17 stags, 4 roes, 2 roebucks, and 5 does), 4 badgers, 4 crickets, 18 mice, 1 haymouse, 6 oxen, 6 lambs, 17 sheep, 2 gazelles, 2 pigs, 11 otters, 9 cattle, 3 kine, 7 calves, 1 steer, 4 bulls (excluding of course, John Bull, who shows up 3 times), 10 squirrels, 5 rabbits, 1 coney, 1 lev'ret, 14 cats, 24 dogs (one, at least, is a great Dane), 3 camels, 2 stoats, 8 goats, 2 ponies, 1 monkey, 1 mackerel, 3 herring, 7 trout, 1 eel, 7 salmon, 5 dolphins, 2 goldfish, and a minnow, together with twenty-odd fish, 9 animals, and 26 just plain beasts. (Should we add dragon [11], mermaid [3], and sphinx [1]?) The profusion of animals here-both on the hoof, as it were, and in the vehicle of a metaphor-may give new force to Yeats's complaint of desertion at the waning of his inventive power:

I sought a theme and sought for it in vain,

I sought it daily for six weeks or so.

Maybe at last, being but a broken man,

I must be satisfied with my heart, although

Winter and summer till old age began

My circus animals were all on show.

Although these homely catalogues represent a fairly unsophisticated approach to Yeats's poetry, they will perhaps suggest the kinds of dis- 
covery that are now made easier and surer. Ultimately, we hope that this concordance and others to follow (the Blake in particular) will stimulate exploration of the strange, dazzling, highly organized but often ill-charted worlds created by symbolist and mythopoeic genius.

\section{Basic Text and Format}

With the permission of The Macmillan Company and Colonel Russell $\mathrm{K}$. Alspach, this concordance is based upon the superb Variorum Edition of the Poems of W. B. Yeats, edited by Peter Allt and Colonel Alspach (New York, 1957). The technique of preparing the text for the computer was about the same as that developed for the first volume in this series, A Concordance to the Poems of Matthew Arnold (Ithaca, 1959). The lines of Yeats's verse were punched on IBM cards (one line per card) and "verified"; speaker identifications, stage directions, dedications, and all like material not bearing line numbers were omitted. Page numbers and line numbers as shown in the variorum edition were added to the cards by a semiautomatic process. Lines too long for a single card were divided and punched on two (or more) cards with the same line number; the first portion of the line was followed and the last portion preceded by three spaced periods. Variant lines, with certain exceptions as noted below (see "Variants," p. ix), were put together from the Allt and Alspach collations and punched, each with a " $v$ " preceding the line number, then interfiled by page in the main deck. A single title card for each poem, containing an abbreviated title designed to serve as identifying information (for the full list of abbreviations see pp. xv-xxvi) was placed at the head of the cards representing the poem. There was one important departure from the Arnold procedure: complete titles and variant titles of all poems, less subtitles and other prefatory matter, were punched in the same way as lines of verse, but with " $\mathrm{T}$ " in the line-number position, so that they could be indexed. Where digits occurred in titles, they were spelled out within brackets.

After proofreading, the material on the cards was transferred to magnetic tape. The 704 was then programmed to search the tape and index alphabetically every word on it, with some exceptions (see "Omitted Words," p. xi), by listing all lines of verse in which the word occurred, together with the identifying information: page number, abbreviated title, and line number ( or $\mathrm{T}$ ) preceded by $\mathrm{v}$ for variant lines or titles. The order in which the lines of verse fall under each of the index words is the order in which the cards were fed onto tape-that is, page and line order in the variorum edition. As with the Arnold concordance, the final IBM list, spaced into pages, was reproduced for publication by 
an offset process, and a table of index words in order of frequency was provided in an appendix.

Several features of this volume represent sophistications of the techniques developed for Arnold (a twentieth-century poet deserves more help from modern technology than a nineteenth). Particulars of these are given in the Programmer's Preface ( $p . x x i x$ ), but three brief statements must be made here. First, a new print-wheel design made it possible to include punctuation symbols on the text cards and to show them on the concordance page. It might be noted that since apostrophes and single quotation marks would be indistinguishable, all quotation marks are double, even those within quotations. Second, a cross-reference routine was devised whereby the hyphen was treated in the indexing as a letter, not as a space (the computer recognizes only these two categories). Each hyphenated word thus appears as an index entry, and a cross reference is provided from the second (third, fourth, and so on) part of the word to the whole entry, under which the lines of text appear. An occasional word not hyphenated has been held together, for obvious reasons, as though it were (e.g., FOL DE ROL). Finally, the new program made it possible to exercise a certain amount of editorial judgment on an unpaged listing of the concordance text, then to incorporate changes in the final paged list. Thus partial listings of certain homographs have been provided (ART, MIGHT, and WLL) by the simple device of dropping the unimportant meanings. Conceivably, a hardier editor might in much the same way discriminate all homographs, to the limit of his discernment and endurance. But, as with nearly all other concordances, the user can make his own discriminations here (and they might not always be the same as an editor's) by looking through the quoted lines of text. For an illustration of what can be achieved with our elegant new techniques, see the nosE entries where I have disentangled one of Yeats's important symbols from the occurrences of ROSE as a verb.

In the Appendix to this volume will be found, listed in order of frequency, the 10,666 words of Yeats's poetic vocabulary which are indexed in the concordance. The total of 10,666 (10,465 indexed, 3 partially indexed, 198 wholly omitted), like the total of 10,097 for Arnold, is somewhat inflated by the way in which hyphenated and apostrophized words have been handled, and individual frequencies are swollen by the presence of variant lines. Moreover, it may be useful to repeat here a caution set down in the Arnold Preface: since the Appendix shows raw frequencies, transcribed from the indexing tapes-MAN (456 occurrences), MAN's (54), MEN (263), and MEN's (23) are separate entriesthe list cannot be compared directly with other lists of high-frequency words made up by combining variant forms. 
Yet these figures should offer a number of suggestive facts even to the casual reader. Among the dozen highest frequencies perhaps oLD (575) is the one surprise; the appearance of LOVE (353) and HEART (272) could have been foretold. In a lower range, parts of the body are unexpectedly prominent. BODY itself has 104 occurrences, BODIES 34, EYES 244, EYE 86, FACE 131, HAIR 138, FEET 108, FOOT 34, BREAST 76, ARMS 58 , LIPS 88 , and моuтн 39. (Here, of course, the figures are occasionally padded by homographs.) At the lowest range one is struck by the abundance of nonce words in some of Yeats's most brilliant lyrics. Consider, for an example, the opening stanza of "Byzantium":

The unpurged images of day recede;

The Emperor's drunken soldiery are abed;

Night resonance recedes, night-walkers' song

After great cathedral gong;

A starlit or a moonlit dome disdains

All that man is,

All mere complexities,

The fury and the mire of human veins.

The italicized forms occur nowhere in Yeats outside this poem; moreover, "abed," "soldiery," "gong," "starlit," and "dome" show up elsewhere only once or twice. It is almost as though on these occasions Yeats rose to a fresh level of poetic discourse.

\section{Variants}

The friends that have it I do wrong

When ever I remake a song,

Should know what issue is at stake;

It is myself that I remake.

So sang Yeats relatively early in his career as maker and remaker of songs. The record of his lifelong struggle for perfection of the work and of the self may be read in the thousands of collations printed by Allt and Alspach. In putting together variant lines from these collations, I have followed the numbering scrupulously, with one exception: variants of a refrain line were punched once only, with REF in the line-number position (refrain lines in the main text were all given proper line numbers).

While I have striven not to leave out any important part of Yeats's self, and have thus swelled this volume and padded the frequency lists with numerous minor variants-some, alas, probably introduced by editors or 
printers, not by the poet-certain omissions have seemed desirable, if only to confine the work to a volume. The following variants listed in Allt and Alspach have therefore not been recorded:

1) Variants involving punctuation, capitalization, italics, or accents only (for these could not be shown in the IBM print).

2) Variants involving only material not given a line number in the main text (and therefore not punched): speaker identifications, stage directions, subtitles, and the like.

3) Variants involving simply the renumbering or transposition of identical lines or portions of lines that are relatively close together-that is, on the same page of Allt and Alspach (e.g., p. 4, line 34 and var. line 35). Lines moved from one location to another, or from one poem to another, were punched in both.

4) Variants involving only the apostrophization, abbreviation, contraction, or expansion of single words (e.g., "altho" " for "although," "St." for "Saint," "Ha'pence" for "halfpence," and "H___s" for "Horton's").

5) Variants involving the separation or joining of two words where no word concerned is "significant"-that is, included in the index. Thus "I'll" for "I will," "what's" for "what is," "he's" for "he has," and the like, were not punched ("will" as a verb is nonsignificant, as are all the other words above). But "a while" for "awhile" was punched, since both "while" and "awhile" are significant words.

6) Most variants produced by obvious misprints in one or another edition of Yeats (e.g., "beech-hole" for "beech-bole," p. 278, line 36). Identification of misprints has been conservative, with the result that some unlikely but possible readings are included. I have also thought it best to keep a few apparent misprints that have acquired currency by surviving many printings (see, for example, p. 39, var. line 158 and p. 121, var. line 6). The following misprints, however, appearing in lines which had to be punched, have been corrected silently: "hundrd" for "hundred," p. 8, var. line 85a; "unwieldly" for "unwieldy," p. 18, var. line 268; "lounging" for "lunging," p. 41, var. line 181; "langour" for "languor," p. 44, line 223; "dread-dimmed" for "dream-dimmed," p. 164, var. line 1; "Drumhair" for "Drumahair," p. 207, var. line 11; "Any" for "And," p. 273, line 64; "their" for "there," p. 279, var. line 53; "clanguor" for "clangour," p. 382, line 9; "at" for "a," p. 392, var. line 17; "An" for “And," p. 392, var. line 25; "wndow" for “window," p. 694, line 95; "howewards" for "homewards," p. 757, line 202; and "comortable" for "comfortable," p. 780, line 6.

7) Variant titles to groups of poems after the first listing in Allt and Alspach. Thus "Momentary Thoughts" has been punched once only, as a variant title to poem No. 105, p. 260. 
8) Variant titles which are simply first lines of poems.

9) Variants involving spelling only. To introduce these would not only have required extensive cross-referencing of a kind the computer could not accomplish unaided, but might also have masked the consistency of spelling in Yeats's final text. I have, however, preserved a few variants that seemed for one reason or another to be of interest or to offer difficulties (e.g., "phantasy" for "fantasy," "faery" for "fairy," and "chaunt" for "chant"). Proper names, of course, are a special case. Most variant names vary only slightly and should give little trouble (e.g., "Hoolihan" for "Houlihan," and "Kyle-na-gno" for "Kyle-na-no"); most of those that might give trouble (e.g., "Usheen" for "Oisin") are listed helpfully on pages 1 and 105 of Allt and Alspach. The connoisseur of Irish spellings will be sorry to have lost "Coulte" and "Moharabuiee" (which occur only as variants) but will perhaps be satisfied with "Shee," "Cu," "Cann," and "Cola," which survive (a number of variant names, "Usheen" among them, show up in the concordance by reason of their occurrence in lines that contain other, significant variants ).

Besides the types listed above, a very small number of miscellaneous variants have been omitted for what seemed compelling reasons. These include an occasional line all of whose variants were incorporated separately in variant lines or half-lines already punched, and an occasional curiosity such as var. line 418, p. 242: "O! O! O! But no, that is not it" for "O! O! O! O! But no, that is not it." (Actually, no matter how hard we might punch this particular line, we could not get it to show up anywhere, all words in it being nonsignificant.)

It might be worth remarking, finally, that the omissions do not include any variants of hyphenation (save for a handful of proper names). As a consequence, the user must realize, three forms of a substantial number of terms are to be found in the concordance (e.g., HARPSTRING, HARP STRING, and HARP-STRING).

\section{Omitted Words}

Our computer routines have made it possible not only to offer selective listings of the most troublesome homographs, but also to provide frequencies of the omitted words. Words in the first list, below, are indexed only in the forms shown; words in the second list are omitted from the index altogether. DoEs, MAY, and wILT were listed for editing, then dropped, since neither of the first two occurs as a noun, nor does the last occur in the sense of "droop"; TILL, which has only two occurrences as a noun, none as a verb, might have been dropped or edited, but the 145 occurrences as a preposition or conjunction were thought to be of sufficient interest to warrant retaining them. 


\section{PARTIALLY LISTED}

$\begin{array}{llll}\text { ART } & \text { (noun) } & 12 & (12 \text { occurrences as verb omitted) } \\ \text { MIGHT } & \text { (noun) } & 12 & (74 \text { occurrences as verb omitted) } \\ \text { WILL } & \text { (noun) } & 32 & (262 \text { occurrences as verb omitted) }\end{array}$

OMITTED ENTIRELY

\begin{tabular}{|c|c|c|c|c|c|c|c|}
\hline $\mathrm{A}$ & 2841 & HADST & 3 & $M E$ & 464 & THEIR & 633 \\
\hline AGAIN & 99 & HAS & 364 & MUST & 131 & THEIRS . & 5 \\
\hline $\mathrm{AH}$ & 88 & HAST & 17 & MY & 1118 & THEM & 219 \\
\hline Lso & 11 & НАТН & 26 & MYSEL' & 1 & THEMSELVES & 12 \\
\hline CTHOUGH & 48 & HAVE & 850 & MYSELF & 18 & THEN & 168 \\
\hline M & 165 & $\mathrm{HE}$ & 789 & NEITHER & 31 & THERE & 468 \\
\hline AN & 300 & HE'D & 12 & no & 526 & THERE'S & 46 \\
\hline AND & 6023 & HE'LL & 5 & NOR & 209 & THEREFORE & 21 \\
\hline NOTHER & 51 & HER & 737 & NOT & 540 & THERE'LL & 5 \\
\hline ANOTHER'S & 10 & HERE & 77 & now & 337 & THESE & 166 \\
\hline ARE & 589 & HERE'S & 11 & o & 318 & THEY & 567 \\
\hline$\Gamma$. & 469 & HERS & 10 & $\mathrm{o}^{\prime}$ & 3 & THEY'D . & 6 \\
\hline$B E$ & 485 & HERSELF & 13 & OF & 3320 & THEY'LL & 5 \\
\hline CAUSE & 158 & HE's & 9 & $\mathrm{OH}$ & 64 & THEY'RE & 10 \\
\hline EN & 111 & HIM & 289 & ON. & 992 & THEY'VE & 2 \\
\hline TTH & 29 & HIMSELF & 22 & OR & 799 & THINE & 23 \\
\hline $\mathrm{JT}$ & 974 & HIS & 1081 & OTHER & 82 & THIS & 306 \\
\hline BY & 514 & HOw & 183 & OTHER'LL & 1 & THOSE & 229 \\
\hline N & 267 & I & 2132 & OTHERS & 19 & THOU & 107 \\
\hline ANNOT & 65 & II & 1 & OTHER'S & 9 & THOUGH & 218 \\
\hline ANST & 1 & III & 1 & OTHERS' & 1 & THOUL'T & 1 \\
\hline ULD & 165 & IV & 2 & OUR & 318 & THOU'RT & 1 \\
\hline & 1 & $I^{\prime}$ & 2 & OURS & 4 & THRO' & 2 \\
\hline$D E$ & 9 & I'D & 57 & OURSELVES & 2 & THROUGH & 161 \\
\hline D & 95 & IF & 281 & $\mathrm{P}$ & 1 & THUS & 30 \\
\hline DST & 1 & I'LL & 42 & 's & 1 & THY & 123 \\
\hline DID'st & 1 & IM & 13 & SHALL & 158 & THYSELF & 2 \\
\hline Do . & 138 & IN & 2088 & SHALT & 14 & 'TIS & 24 \\
\hline ES & 20 & IN'T & 2 & SHE & 361 & то & 1751 \\
\hline N'T & 1 & INTO & 179 & SHE'D & 7 & Too & 88 \\
\hline ST & 4 & Is & 922 & SHE'LL & 2 & T'OTHER & 3 \\
\hline OTH & 4 & IS'T & 1 & SHOULD & 123 & T'OTHER'S & 1 \\
\hline $\mathrm{ACH}$ & 79 & IT & 713 & so & 339 & 'TWAS & 16 \\
\hline THER & 10 & ITS & 188 & 'TH & 3 & 'TWERE & 12 \\
\hline & 3 & IT'S & 24 & THAT & 2357 & 'TWILL & 2 \\
\hline $\mathrm{DR}$ & 1007 & ITSELF & 17 & THAT'S . & 40 & 'TWOULD & 3 \\
\hline $\mathrm{M}$ & 665 & I'VE & 20 & THE & 8436 & UPON & 508 \\
\hline & 610 & MAY & 245 & THEE & 68 & US & 174 \\
\hline
\end{tabular}




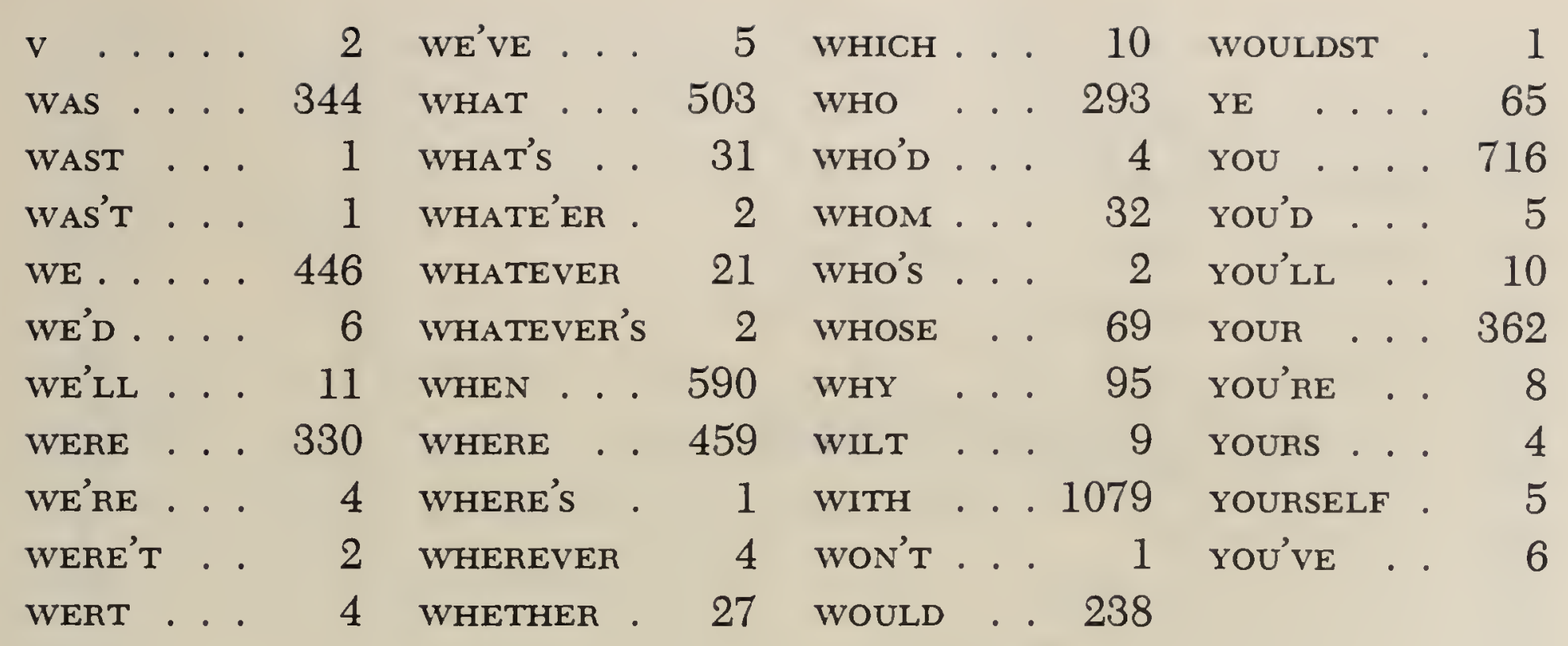

The presence here of low-frequency words may be explained by a desire for consistency. For example, with HE (789), HIS (1,081), and HIM (289) out for obvious reasons it seemed logical to drop HIMSELF, with only 22 occurrences (regrettable as that omission may seem from the work of an Irish poet). But endless controversy might be waged over my selections. Consider the lowly preposition of. Having observed that Yeats liked to form metaphors by connecting vehicle and tenor with "of," I listed and examined all 3,320 occurrences of the word (the computer can provide a list of any given word in about 30 minutes). Scattered through the chaff were the following images, which could not, I suppose, have been collected in any other way:

THE PALE BLOSSOM OF THE MOON

Page

THE OSPREY OF SORROW

THE ANVIL OF THE WORLD

THE FIRE OF SADNESS

42

THE GULPH OF SLEEP

73

THE ROOD OF TIME

83

THE BOUGHS OF LOVE AND HATE

100

GREAT WEBS OF SORROW

101

104

THE WHARVES OF SORROW

115

FLAMING FOUNTS OF DUTY

124

THE GLASS OF OUTER WEARINESS

135

THE FLAMING CIRCLE OF OUR LIFE

135

THE RAVENS OF UNRESTING THOUGHT

136

THE NETS OF WRONG AND RIGHT

147

THE SHADOWY BLOSSOM OF MY HAIR

152

TIIE HORSES OF DISASTER

154

THE PALE FIRE OF TIME

157

LILIES OF DEATH-PALE HOPE, ROSES OF PASSIONATE DREAM 172

THE NETS OF DAY AND NIGHT

175

Line 288 V $415 \mathrm{D}$ 204 


$\begin{array}{llr} & \text { Page } & \text { Line } \\ \text { THE PALE CUP OF THE SEA } & 175 & 14 \\ \text { THE WATERS OF SLEEP } & 218 & 25 \\ \text { THE BURNISHED MIRROR OF THE WORLD } & 228 & 132 \\ \text { THE SHIVERING CASTING-NET OF THE STARS } & 237 & 329 \\ \text { THE LABYRINTH OF HER DAYS } & 260 & 13 \\ \text { THE DIM / IMAGINATIONS OF THEIR EYES } & 272 & 27 / 28 \\ \text { THE GOLDEN TOP OF CARE } & 309 & 20 \\ \text { THE WICK OF YOUTH } & 334 & \mathrm{~V} \\ \text { THE PESTLE OF THE MOON } & 346 & 3 \\ \text { YELLOW-EYED HAWK OF THE MIND } & 349 & 14 \\ \text { THE BALLOON OF THE MIND } & 358 & 2 \\ \text { THE CAT-O'-NINE-TAILS OF THE MIND } & 374 & 42 \\ \text { THE BASIN OF THE MIND } & 478 & 34 \\ \text { THE HONEY-POT OF HIS MIND } & 481 & 21 \\ \text { THIS PRAGMATICAL, PREPOSTEROUS PIG OF A WORLD } & 481 & 26 \\ \text { THOSE BRANCHES OF THE NIGHT AND DAY } & 502 & 68 \\ \text { THE MARE OF TIME } & 529 & 5 \\ \text { THE FOAL OF THE WORLD } & 529 & 6 \\ \text { THE MATERNAL MIDNIGHT OF MY BREAST } & 535 & 7 \\ \text { THE MILL OF THE MIND } & 575 & 10 \\ \text { THE CAVERN OF THE MIND } & 600 & 2 \\ \text { THE FOUL RAG-AND-BONE SHOP OF THE HEART } & 630 & 40 \\ \text { THE BOUGHS OF TIME } & 756 & 178 \\ \text { THE LABYRINTH OF THE MIND } & 785 & 24 \\ & & 5 \\ \end{array}$

Other insignificant words in Yeats, arbitrarily omitted from this index to economize space, may be of like interest to scholars and critics. To prevent any word from being lost forever, we expect to keep on file the magnetic tapes of all texts in the Cornell series.

\section{Abbreviated Titles}

In assigning title abbreviations-as in all things-I have followed the numbering of lines in the variorum edition. Wherever a poem breaks into parts or scenes with separate sequences of numbers, separate titles have been assigned; where numbering is continuous from one section to the next, one title carries over. Yeats's longer titles have not been easy to reduce to fourteen columns of an IBM card, and I have followed no very consistent principle. I have occasionally taken the opening words; more often, I have tried to devise a catch title from words which seemed likely to have lodged in a reader's memory. 
Abbreviations are listed below exactly as they appear in the concordance text. Following each abbreviation the reader will find the full title of the poem and the number of the page on which the poem begins in the variorum edition.

Abbreviation
ABBEY THEATRE
ACCURSED WHO
ACRE OF GRASS
ADAMS CURSE
AGAINST WITCH
ALF POLLEXFEN
ALL SOUL NIGHT
ALL TEMPT ME
AM OF IRELAND
ANASHU VIJAYA
ANCEST HOUSES

ANNE GREGORY

APPARITIONS

APPOINTMENT

ARROW

ASKS FORGIVE

AT ALGECIRAS

BAILE AILLINN

BALLOON MIND

BEFORE WORLD

BEGGAR CRIED

BELOVED DEAD

BELOVED PEACE

BELOVED RHYMES

BEN BULBEN

BLACK CENTAUR

BLACK PIG

BLACK TOWER

BLESS PSALTER

BLESSED

BLOOD AND MOON

BLOOD BOND

BONE OF A HARE
Title

At the Abbey Theatre (Imitated from Ronsard)

'Accursed who brings to light of day'

An Acre of Grass

Adam's Curse

Against Witchcraft

In Memory of Alfred Pollexfen

All Souls' Night: Epilogue to 'A Vision'

All Things can Tempt me

Words for Music Perhaps XX. 'I Am of Ireland'

Anashuya and Vijaya

Meditations in Time of Civil War I. Ancestral Houses

For Anne Gregory

The Apparitions

An Appointment

The Arrow

The Lover asks Forgiveness because of his Many Moods

At Algeciras - A Meditation upon Death

Baile and Aillinn

Page

264

779

575

204

775

360

470

267

526

71

417

492

624

624

199

The Balloon of the Mind

A Woman Young and Old II. Before the World was Made

493

189

358

531

299

175

He wishes his Beloved were Dead

154

157

636

442

161

635

The Black Tower

The Players ask for a Blessing on the Psalteries and on Themselves

The Blessed

The Blood Bond: from the play 'Grania' by George Moore and W. B. Yeats 
BOOK STORIES

BRAVEST ASK

BREAK OF DAY

BROKEN DREAMS

BRONZE HEAD

BROWN PENNY

BYZANTIUM

CAP AND BELLS

CARVED STONE

CAT AND MOON

CATHLEEN PARA

CHANGE BELOVED

CHILD DANCING

CHOICE

CHOSEN

CHURCH STATE

CIRCUS ANIMALS

CLOAK BOAT

CLOTHS HEAVEN

COAT

COLD HEAVEN

COLONEL MARTIN

COLONUS PRAISE

COME RIDE

COMING WISDOM

CONJUNCTIONS

CONSOLATION

COOLE BALLYLEE

COOLE PARK 29

CRADLE SONG

CRAZED GIRL

CRAZED MOON

CRY OF SEDGE

CUCHULAIN COMF

CUCHULAIN SEA

CURSE CROMWELL

DANAAN QUICK

DANCER CRUACH

DANCING DAYS
The Dedication to a Book of Stories selected from

The Irish Novelists

'The bravest from the gods but ask:' $\quad 788$

Towards Break of Day

398

355

618

268

497

159

The Cap and Bells

406

The Cat and the Moon 378

The Countess Cathleen in Paradise

124

He mourns for the Change that has come upon him and his Beloved, and longs for the End of the World

I. To a Child Dancing in the Wind

312

The Choice

A Woman Young and Old VI. Chosen 534

Church and State

553

The Circus Animals' Desertion

629

The Cloak, the Boat, and the Shoes 69

He wishes for the Cloths of Heaven 176

A Coat

320

The Cold Heaven 316

Colonel Martin 594

Colonus' Praise (from 'Oedipus at Colonus') 446

'Come ride and ride to the garden' [from the play

'The Travelling Man,' by Lady Gregory]

773

261

The Coming of Wisdom with Time

Supernatural Songs X. Conjunctions

562

A Woman Young and Old V. Consolation 534

Coole Park and Ballylee, 1931

Coole Park, 1929

A Cradle Song 118

A Crazed Girl 578

The Crazed Moon 487

He hears the Cry of the Sedge 165

Cuchulain Comforted 634

Cuchulain's Fight with the Sea 105

The Curse of Cromwell 580

The Danaan Quicken Tree $\quad 742$

Words for Music Perhaps XXI. The Dancer at Cruachan and Cro-Patrick

Words for Music Perhaps XIX. Those Dancing Days are Gone 
DAWN

DAWN-SONG

DEATH

DEATH OF HARE

DEDICATION

DEEP-SWORN VOW

DEJECTION

DELPHIC ORACLE

DEMON BEAST

DOLLS

DOLLS DRAWINGS

DOLLS FACES

DOR WELLESLEY

DRAWING-ROOM

DREAM OF DEATH

DREAM OF FAERY

DRINKING SONG

DRUNK SOBRIETY

DWELT SYCAMORE

EARL PAUL

EASTER 1916

EGO DOMINUS

ELEMENT POWERS

EMPTY CUP

END OF DAY

EPHEMERA

EVA GORE-BOOTH

EVERLAST VOICE

EVIL OF BELOV

FAERY SONG

FAIRY DOCTOR

FAIRY PEDANT

FALLEN MAJESTY

FALLING LEAVES

FASC DIFFICULT

FATHER CHILD

FATHER OHART

FERENCZ RENYI

FERGUS DRUID

FIDDLER DOONEY

FIRST CONFESS
The Dawn

A Dawn-Song

705

Death

476

A Man Young and Old IV. The Death of the Hare 453

Dedication

790

A Deep-sworn Vow

357

Lines Written in Dejection

343

Words for Music Perhaps XXV. The Delphic

Oracle upon Plotinus

530

Demon and Beast

399

The Dolls

319

Upon a Dying Lady II. Certain Artists bring her Dolls and Drawings

Upon a Dying Lady III. She turns the Dolls' Faces to the Wall

362

To Dorothy Wellesley

363

579

In a Drawing-Room

685

A Dream of Death

123

The Man who Dreamed of Faeryland 126

A Drinking Song

261

A Drunken Man's Praise of Sobriety

591

She Who Dwelt among the Sycamores. A Fancy.

715

739

391

Easter 1916

367

174

454

364

Ephemera

475

141

The Everlasting Voices

He thinks of those who have Spoken Evil of his

Beloved

166

A Faery Song

116

The Fairy Doctor

716

The Fairy Pedant

706

Fallen Majesty

314

The Falling of the Leaves

The Fascination of What's Difficult

260

A Woman Young and Old I. Father and Child 531

The Ballad of Father O'FIart

91

How Ferencz Renyi Kept Silent. Hungary, 1848. 709

Fergus and the Druid

102

The Fiddler of Dooney 178

A Woman Young and Old III. A First Confession 532 
FIRST LOVE

FISH

FISHERMAN

FOLLY COMFORT

FOR DAUGHTER

FOR MY SON

FORGOT BEAUTY

FOUR AGES MAN

FOXHUNTER

FR GILLIGAN

FRAGMENTS

FRIEND ILLNESS

FRIENDS

FRIENDS WRONG

FRIENDS YOUTH

FROM ANTIGONE

FROM JAPANESE

FROM OEDIPUS

GALLERY REVIS

GALWAY RACES

GARRET CELLAR

GEORGE MOORE

GHOST ROG CASE

GIRLS SONG A

GIRLS SONG B

GLOVE CLOAK

GOES FERGUS

GOING THE ROAD

GRAT INSTRUCT

GREAT DAY

GREY ROCK

GREY ROUND

GYRES

HANRAHANS SONG

HAPPY SHEPHERD

HAPPY TOWNLAND

HARP OF AENGUS

HARUN RASHID

HATED PLAYBOY

HAWK
A Man Young and Old I. First Love

451

The Fish

146

The Fisherman 347

The Folly of Being Comforted 199

A Prayer for my Daughter 403

A Prayer for my Son $\quad 435$

He remembers Forgotten Beauty 155

Supernatural Songs IX. The Four Ages of Man 561

The Ballad of the Foxhunter

97

The Ballad of Father Gilligan

132

Fragments

439

A Friend's Illness

267

Friends

315

'The friends that have it I do wrong'

A Man Young and Old VII. The Friends of his Youth

778

455

A Woman Young and Old XI. From the 'Antigone'

Imitated from the Japanese

567

A Man Young and Old XI. From 'Oedipus at Colonus'

459

The Municipal Gallery Revisited

601

At Galway Races

'To Garret or Cellar a wheel I send,'

266

'Moore once had visits from the muse'

787

The Ghost of Roger Casement

792

583

Girl's Song

Words for Music Perhaps VIII. Girl's Song

723

515

The Glove and the Cloak

744

Who Goes with Fergus?

125

'I was going the road one day'

Gratitude to the Unknown Instructors

779

505

590

The Great Day

The Grey Rock

270

At the Grey Round of the Hill 782

The Gyres

564

Red Hanrahan's Song about Ireland 206

The Song of the Happy Shepherd 64

The Happy Townland 213

The Harp of Aengus [prefixed to 1906 version of

'The Shadowy Waters: A Dramatic Poem']

The Gift of Harun Al-Rashid

460

On those that hated 'The Playboy of the Western

$$
\text { World,' } 1907
$$

The Hawk 
HAWTHORN TREE

HE AND SHE

HEART FRIGHT

HEART OF WOMAN

HEART SLEEVE

HELEN LIVED

HER ANXIETY

HER CHRIS TREE

HER COURAGE

HER COURTESY

HER DREAM

HER PRAISE

HER RACE

HER TRIUMPH

HER VISION

HERO GIRL FOOL

HIGH TALK

HIS BARGAIN

HIS CONFIDENCE

HIS DREAM

HIS MEMORIES

HIS PHOENIX

HIS WILDNESS

HOST OF AIR

HOSTING SIDHE

HOUND VOICE

HOUR DAWN

HOUSE SHAKEN

HUDDON DUDDON

HUMAN DIGNITY

IMAGE PAST

IN CHURCH

IN FIRELIGHT

IN TARAS HALLS

IN TIME OF WAR

INDIAN ON GOD

INDIAN TO LOVE

INTO TWILIGHT

IRISH AIRMAN

ISLE IN WATER

ISLE INNISFREE

ISLE STAT I 1

ISLE STAT I 2
The Wicked Hawthorn Tree

Supernatural Songs VI. He and She

559

Why should the Heart take Fright?

781

151

'The heart well worn upon the sleeve. . ' 790

When Helen Lived

293

Words for Music Perhaps X. Her Anxiety

517

Upon a Dying Lady VII. Her Friends bring her a Christmas Tree

Upon a Dying Lady VI. Her Courage

365

Upon a Dying Lady I. Her Courtesy

362

Words for Music Perhaps XIII. Her Dream

519

Her Praise

350

Upon a Dying Lady V. Her Race

365

A Woman Young and Old IV. Her Triumph

533

A Woman Young and Old VIII. Her Vision in the Wood

536

The Hero, The Girl, and the Fool

447

High Talk

622

Words for Music Perhaps XIV. His Bargain

520

Words for Music Perhaps XI. His Confidence

His Dream

517

253

A Man Young and Old VI. His Memories

454

353

His Phoenix

458

A Man Young and Old X. His Wildness

143

140

621

Hound Voice

302

The Hour before Dawn

264

Upon a House shaken by the Land Agitation

787

A Man Young and Old II. Human Dignity 452

An Image from a Past Life

389

735

737

In the Firelight

609

In Tara's Halls

406

A Meditation in Time of War

The Indian to His Love

77

Into the Twilight

An Irish Airman Foresees his Death

328

To an Isle in the Water

The Lake Isle of Innisfree

117

The Island of Statues (Act I, Scene 1)

645

The Island of Statues (Act I, Scene 2) 
ISLE STAT I 3

ISLE STAT II 1

ISLE STAT II 2

ISLE STAT II 3

JANE AND JACK

JANE BISHOP

JANE GROWN OLD

JANE JUDGMENT

JANE MOUNTAIN

JANE ON GOD

JANE REPROVED

JANE TALK BISH

JOHN KINSELLA

KANVA ON SELF

KING NO KING

LADYS 1ST SONG

LADYS 2ND SONG

LADYS 3RD SONG

LAPIS LAZULI

LAST CONFESS

LEADERS CROWD

LEDA AND SWAN

LEGEND

LIFE

LIVING BEAUTY

LOFTY THINGS

LONG-LEG FLY

LONG SILENCE

LOSS OF LOVE

LOVE AND DEATH

LOVE SONG

LOVERS QUARREL

LOVERS SONG

LOVES LONENESS

LULLABY

MAD AS MIST

MAD KING GOLL
The Island of Statues (Act I, Scene 3)

The Island of Statues (Act II, Scene 1)

The Island of Statues (Act II, Scene 2)

658

The Island of Statues (Act II, Scene 3)

662

Words for Music Perhaps IV. Crazy Jane and Jack the Journeyman

Words for Music Perhaps I. Crazy Jane and the Bishop

666

511

507

Words for Music Perhaps VIII. Crazy Jane grown old looks at the Dancers

Words for Music Perhaps III. Crazy Jane on the Day of Judgment

Crazy Jane on the Mountain

$\begin{array}{lll}\text { Words for Music Perhaps } & \text { V. Crazy Jane on God } 512 \\ \text { Words for Music Perhaps } & \text { II. Crazy Jane Reproved } 509\end{array}$

Words for Music Perhaps VI. Crazy Jane talks with the Bishop

513

John Kinsella's Lament for Mrs. Mary Moore

620

Kanva on Himself

723

King and No King

258

The Lady's First Song

572

The Lady's Second Song

572

The Lady's Third Song

573

Lapis Lazuli (For Harry Clifton)

565

A Woman Young and Old IX. A Last Confession

538

The Leaders of the Crowd

398

Leda and the Swan

441

A Legend. A drowned city is supposed to lie under the waters of Lough Gill.

724

Life

686

The Living Beauty

333

Beautiful Lofty Things $\quad 577$

Long-Legged Fly

617

Words for Music Perhaps XVII. After Long Silence

The Lover mourns for the Loss of Love

680

Love and Death

717

Love Song. From the Gaelic.

726

A Lover's Quarrel among the Fairies

574

The Lover's Song

518

Words for Music Perhaps

XII. Love's Loneliness

522

Words for Music Perhaps XVIII. Mad as the Mist and Snow

523

The Madness of King Goll 
MAGI

MAGIC DRUM

MAID QUIET

MAIDS 1ST SONG

MAIDS 2ND SONG

MAN AND ECHO

MANS SONG

MARCH SONGS 1

MARCH SONGS 2

MARCH SONGS 3

MASK

MEETING

MEMORY

MEMORY YOUTH

MEN IMPROVE

MERMAID

MERU

MODEL LAUREATE

MOHINI CHATTER

MOLL MAGEE

MOODS

MOSADA 1

MOSADA 2

MOSADA 3

MOTHER OF GOD

MOUNTAIN TOMB

MOURN THEN ON

MY DESCENDANTS

MY HEART BEAT

MY HOUSE

MY TABLE

NATIVITY

NEEDLES EYE

NETTLESHIP

NEVER GIVE ALL

NEW FACES

NEWS ORACLE

NIGHT COME

NINETEEN 19

NINETEENTH CEN

NO SECOND TROY

O DO NOT LOVE

OIL AND BLOOD
The Magi

Supernatural Songs VII. What Magic Drum?

Maid Quiet

171

The Chambermaid's First Song

574

The Chambermaid's Second Song

575

The Man and the Echo

632

Words for Music Perhaps IX. Young Man's Song 516

Three Marching Songs (I)

Three Marching Songs (II)

613

Three Marching Songs (III)

614

615

The Mask

A Woman Young and Old X. Meeting

539

Memory

350

A Memory of Youth

313

Men Improve with the Years

329

A Man Young and Old III. The Mermaid

452

Supernatural Songs XII. Meru

563

A Model for the Laureate

597

Mohini Chatterjee

495

The Ballad of Moll Magee

The Moods

142

Mosada (Scene I)

690

Mosada (Scene II)

695

Mosada (Scene III)

699

The Mother of God

499

The Mountain Tomb

311

737

Meditations in Time of Civil War IV. My

Descendants

422

Why does my Heart beat so?

781

Meditations in Time of Civil War II. My House

419

Meditations in Time of Civil War III. My Table

421

625

A Nativity

562

On Mr. Nettleship's Picture at the Royal

688

Hibernian Academy

202

The New Faces

435

611

News for the Delphic Oracle

317

That the Night Come

428

485

256

No Second Troy

211

483 
OISIN 1

OISIN 2

OISIN 3

OLD FISHERMAN

OLD MEMORY

OLD MEN ADMIRE

OLD MEN BE MAD

OLD MOTHER

OLD PENSIONER

OLD TOM AGAIN

OLD WICKED MAN

ON GOING HOUSE

ON WOMAN

ORAHILLY

OWEN AHERNE

PARDON FATHERS

PARN FUNERAL 1

PARN FUNERAL 2

PARNELL

PARNELLITES

PARTING

PAST GREATNESS

PAUDEEN

PEACE

PEACOCK

PEOPLE

PERFECT BEAUTY

PHANTOM HATRED

PHANTOM SHIP

PHASES OF MOON

PILGRIM

PITY OF LOVE

PLAYER QUEEN

PLEADS FRIEND

POET BELOVED

POLIT PRISONER

POLITICS

PRAYER OLD AGE

PRESENCES

PRIEST FAIRY

PROPERTIUS

QUARREL IN AGE
The Wanderings of Oisin (Book I)

The Wanderings of Oisin (Book II)

The Wanderings of Oisin (Book III)

47

The Meditation of the Old Fisherman

90

Old Memory

201

The Old Men Admiring Themselves in the Water 208

Why should not Old Men be Mad?

625

The Song of the Old Mother

150

The Lamentation of the Old Pensioner 131

Words for Music Perhaps XXIV. Old Tom Again 530

The Wild Old Wicked Man

587

A Prayer on going into my House

On Woman

371

345

The O'Rahilly

584

Owen Aherne and his Dancers

449

Pardon, Old Fathers

269

Parnell's Funeral I

541

Parnell's Funeral II

542

Parnell

590

Come Gather Round Me, Parnellites

586

A Woman Young and Old VII. Parting

535

He thinks of his Past Greatness when a Part of the Constellations of Heaven

177

Paudeen

291

Peace

258

II. The Peacock

310

The People

351

He tells of the Perfect Beauty

Meditations in Time of Civil War VII. I see

164

Phantoms of Hatred and of the Heart's Fullness and of the Coming Emptiness

The Phantom Ship

425

The Phases of the Moon 372

The Pilgrim $\quad 592$

The Pity of Love 119

A Song from 'The Player Queen' 308

The Lover pleads with his Friend for Old Friends 172

A Poet to his Beloved 157

On a Political Prisoner 397

Politics 631

A Prayer for Old Age $\quad 553$

Presences 358

The Priest and the Fairy 728

A Thought from Propertius 355

Quarrel in Old Age 
QUATRAIN APHOR QUEEN MAEVE

RAGGED WOOD

REALISTS

RECONCILIATION

REED WHISPERER

REMEMBRANCE

REMORSE SPEECH

REPRISALS

REPROVE CURLEW

RESULT THOUGHT

RIBH AT TOMB

RIBH CHRISTIAN

RIBH ECSTASY

RIBH PATRICK

ROAD AT DOOR

ROBARTES DANCE ROBERT GREGORY ROGER CASEMENT

ROSE IN HEART

ROSE OF BATTLE ROSE OF PEACE ROSE OF WORLD ROSE TREE ROSE UPON ROOD ROSY CROSS ROUND TOWER RUN PARADISE SAD SHEPHERD SAIL BYZANTIUM SAINT HUNCH SALLEY GARDENS SCHOLARS

SCHOOL CHILDR SECOND COMING SECRET ROSE SECRETS OF OLD SEEKER

SELF AND SOUL SEPTEMBER 1913 SEVEN SAGES
Quatrains and Aphorisms

The Old Age of Queen Maeve

180

The Ragged Wood

210

The Realists

309

Reconciliation 257

While I, from that reed-throated whisperer 320

Remembrance $\quad 704$

Remorse for Intemperate Speech $\quad 506$

Reprisals

791

He reproves the Curlew

155

The Results of Thought

504

Supernatural Songs I. Ribh at the Tomb of Baile and Aillinn

Supernatural Songs V. Ribh Considers Christian Love Insufficient

Supernatural Songs III. Ribh in Ecstasy

Supernatural Songs II. Ribh denounces Patrick

Meditations in Time of Civil War V. The Road at my Door

423

Michael Robartes and the Dancer

In Memory of Major Robert Gregory

Roger Casement (After Reading 'The Forged

Casement Diaries' by Dr. Maloney)

581

The Lover tells of the Rose in his Heart

The Rose of Battle

The Rose of Peace

The Rose of the World

The Rose Tree

To the Rose upon the Rood of Time 100

A Song of the Rosy Cross 744

Under the Round Tower

331

Running to Paradise

300

The Sad Shepherd

Sailing to Byzantium

4.07

The Saint and the Hunchback

Down by the Salley Gardens

90

The Scholars

Among School Children

443

The Second Coming

401

The Secret Rose

A Man Young and Old IX. The Secrets of the Old 457 The Seeker. A Dramatic Poem-in Two Scenes.

681

A Dialogue of Self and Soul

477

September 1913

289

The Seven Sages 
SEVEN WOODS

SEVERED HEAD

SHADOW WATER A

SHADOW WATER B

SHEP GOATHERD

SINGING HEAD

SIXTEEN DEAD

SOLOMON SHEBA

SOLOMON WITCH

SONG

SONG DEIRDRE 1

SONG DEIRDRE 2

SONG DEIRDRE 3

SONG FAERIES

SONG OF FOOL

SONGS BURDEN 1

SONGS BURDEN 2

SONGS BURDEN 3

SONGS FOOL 1

SONGS FOOL 2

SONGS PLAY 1

SONGS PLAY 2

SONGS REWRIT 1

SONGS REWRIT 2

SORROW OF LOVE

SPEAKS HEARERS

SPILT MILK

SPINNING SONG

SPIRIT MEDIUM

SPUR

STARES NEST

STATES HOLIDAY

STATISTICS

STATUES

STICK INCENSE

STOLEN CHILD

STONE CROSS

STREAM AND SUN

STREET DANCERS

STUDENTS AGIT
In the Seven Woods

Alternative Song for the Severed Head in 'The

King of the Great Clock Tower'

The Shadowy Waters [first version, 1900]

747

The Shadowy Waters [second version, 1906]

221

Shepherd and Goatherd

338

The Singing Head and the Lady

789

Sixteen Dead Men

395

Solomon to Sheba

332

Solomon and the Witch

387

A Song

334

Queen Edaine [Songs from Deirdre I]

771

Songs from Deirdre II

777

Songs from Deirdre III

777

Song of the Faeries

643

Another Song of a Fool

381

Three Songs to the One Burden (I)

605

Three Songs to the One Burden (II)

606

Three Songs to the One Burden (III)

608

Two Songs of a Fool (I)

380

Two Songs of a Fool (II)

381

Two Songs from a Play (I)

437

Two Songs from a Play (II)

438

Two Songs Rewritten for the Tune's Sake (I)

550

Two Songs Rewritten for the Tune's Sake (II)

552

The Sorrow of Love

The Lover speaks to the Hearers of his Songs in Coming Days

Spilt Milk

Spinning Song

The Spirit Medium

599

The Spur

591

Meditations in Time of Civil War VI. The Stare's Nest by my Window

424

The Statesman's Holiday

626

Statistics

485

The Statues

610

A Stick of Incense

619

The Stolen Child

The Old Stone Cross

598

Stream and Sun at Glendalough

506

Street Dancers

731

On hearing that the Students of our New

University have joined the Agitation

against Immoral Literature

262 
SUMMER SPRING

SWANS AT COOLE

SWEET DANCER

SWIFTS EPITAPH

SYMBOLS

THERE

THESE CLOUDS

THOSE IMAGES

THREE BEGGAHS

THREE BUSHES

THREE HERMITS
THREE MONUMENT
THREE MOVEMENT
THREE THINGS
TO A FRIEND
TO A POET

TO A SHADE

TO A SQUIRREL

TO HIS HEART

TO IRELAND

TO SAME TUNE 1

TO SAME TUNE 2

TO SAME TUNE 3

TO SOME I TALK

TO WEALTHY MAN

TOM CRUACHAN

TOM LUNATIC

TOM OROUGHLEY

TOWER

TRAV PASSION

TWO KINGS

TWO TITANS

TWO TREES

TWO YEAR LATER

UNAPPEAS HOST

UNDER SATURN

UNDER THE MOON

UNWORTH PRAISE
A Man Young and Old VIII. Summer and Spring

The Wild Swans at Coole

456

322

Sweet Dancer

568

Swift's Epitaph

Symbols

493

484

Supernatural Songs IV. There 557

These are the Clouds

265

Those Images

The Three Beggars

The Three Bushes (An Incident from the 'Historia

Mei Temporis' of the Abbé Michel de

Bourdeille)

569

The Three Hermits

298

460

485

521

Words for Music Perhaps XV. Three Things

290

To a Poet, who would have me Praise certain Bad

Poets, Imitators of $\mathrm{His}$ and Mine

262

To a Shade

292

To a Squirrel at Kyle-na-no

359

To his Heart, bidding it have no Fear 158

To Ireland in the Coming Times 137

Three Songs to the Same Tune (I) 544

Three Songs to the Same Tune (II) 545

Three Songs to the Same Tune (III) 547

To Some I have Talked with by the Fire 136

To a Wealthy Man who promised a Second

Subscription to the Dublin Municipal Gallery

if it were proved the People wanted Pictures 287

Words for Music Perhaps XXIII. Tom at

Cruachan

529

Words for Music Perhaps XXII. Tom the Lunatic 528

Tom O’Roughley

337

The Tower

409

The Travail of Passion

172

The Two Kings

276

The Two Titans. A Political Poem. 687

The Two Trees

134

II. Two Years Later

312

The Unappeasable Host 146

Under Saturn

390

209

259 
VACILLATION

VALLEY LOVERS

VERONIC NAPKIN

VISION ROBART

WANDER AENGUS

WAR POEM

WELL AND TREE

WHAT THEN

WHAT IVAS LOST

WHEEL

WHENCE COME

WHERE BOOKS GO

WHITE BIRDS

WISDOM

WISDOM DREAMS

WITCH

WITCH VIVIEN

WITHER BOUGHS

WOMAN HOMER

WOMANS BEAUTY

WOODS OF COOLE

WORDS

YOU ARE OLD

YOU ARE SAD

YOU CONTENT

YOUNG BEAUTY

YOUNG GIRL

YOUR HEART

YOUTH AND AGE
Vacillation

He tells of a Valley full of Lovers

163

Veronica's Napkin

483

The Double Vision of Michael Robartes 382

The Song of Wandering Aengus 149

On being asked for a War Poem $\quad 359$

The Well and the Tree $\quad 780$

What Then? 576

What Was Lost $\quad 591$

The Wheel 434

Supernatural Songs VIII. Whence Had They Come? 560

Where My Books Go

739

The White Birds 121

Wisdom $\quad 440$

Wisdom and Dreams 743

I. The Witch 310

Time and the Witch Vivien $\quad 720$

The Withering of the Boughs 203

A Woman Homer Sung 254

A Woman's Beauty is like a white frail Bird 784

I walked among the Seven Woods of Coole [prefixed

to 'The Shadowy Waters: A Dramatic Poem'] 217

Words

255

When You are Old 120

When you are Sad 738

Are You Content? 604

To a Young Beauty 335

To a Young Girl 336

Why does your Heart beat thus? 785

Youth and Age

\section{Acknowledgments}

The beginning of work on this volume was made possible by a grantin-aid from the American Council of Learned Societies; at a later stage support was given from the grant-in-aid program of the Cornell Department of English; throughout, we have been dependent upon services provided by the International Business Machines Corporation, the Cornell Computing Center in Ithaca, and the Cornell Aeronautical Research Laboratory in Buffalo, New York.

These formal announcements scarcely reveal the warm sense of obligation I feel to the individuals who placed their confidence in this venture and gave it their help: William Andrus, now Director of Standards for IBM (who gave the Arnold concordance its start and nursed this one 
along at a critical time); J. A. Kearns, University and Research Institute Representative of IBM; Robert Hoopes, formerly Vice President of the A.C.L.S. and now Dean of the Faculty at Michigan State University-Oakland; John Hastie, Coordinator of Research at Cornell University; Richard Lesser, Director of the Cornell Computing Center; and Theodore P. Wright, Chairman of the Board of Directors, Ira G. Ross, President, and John J. O'Neil, Vice President, of the Cornell Aeronautical Laboratory. The generous support given us by the Laboratory deserves particular mention: it included not only the arrangement of time on the computer together with operating services, but the purchase of print wheels for our exclusive use. This significant investment in the humanities on the part of a corporation committed to scientific research is most gratefully appreciated.

I am further indebted to Miss Laura Franklin, Associate Professor of English at Nebraska State Teachers College, Wayne, who gallantly surrendered her prior claim to the variorum text; to Colonel Alspach, first for passing the rights to me, then for continuing kindly advice; and to Marshall Cohen and George Rice at the Aeronautical Laboratory, who patiently and expertly guided our use of facilities there. In Ithaca, Samuel Miles Weber, Mrs. Marilyn Paul, and Mrs. Elizabeth Savage cheerfully undertook proofreading and editorial chores. The supervisory committee (including the late Stephen E. Whicher) stood loyally ready with counsel of many kinds. Again, I must particularly thank Professor William R. Keast, whose lively interest and encouragement made all difficulties manageable. But this time it is gratifying not to have to thank James Painter, who appears in this volume in his rightful place.

Ithaca, New York

S. M. Parrish

September 1962 
